\title{
Reescrituras divulgativas del mito cidiano. Descripción y análisis de adaptaciones y versiones contemporáneas representativas del Cantar de Mio Cid'
}

\author{
The Spread of Common Rewritings of the Cid Myth. \\ Description and Analysis of Contemporary Representative Adaptations \\ and Versions of the Cantar de Mio Cid
}

\author{
ALDO DAPARTE JORGE \\ IES Primero de Marzo (Baiona, Pontevedra) \\ España \\ aldodaparte@edu.xunta.es
}

(Recibido 25-OI-20I4; aceptado 07 -O7-20I4)

\begin{abstract}
Resumen. Las polémicas adaptaciones de los clásicos al servicio de los mediadores en la enseñanza literaria o de la divulgación de obras canónicas han generado una literatura en segundo grado marcada por ricas relaciones hipertextuales (Genette). El objetivo de este trabajo es dar una visión panorámica de los elementos textuales y paratextuales implicados en una selección representativa de adaptaciones de la materia cidiana, preferentemente gestadas con intención didáctica, debidamente contextualizadas en la tradición de adaptaciones del Cantar de Mio Cid. Dicho análisis permite comprobar los rasgos específicos que caracterizan este proceso, sustancialmente distinto al seguido en la reescritura de otras obras del canon español, debido a factores como las fuentes histórico-legendarias y literarias de la materia argumental, la forma del relato o su performance.
\end{abstract}

Palabras clave: Promoción de la lectura; programa de lectura; poesía épica; Cantar de Mio Cid; análisis literario.
Summary. The controversial adaptations of some classic works undertaken by some mediators of literary Teaching and by the spreading of canonical works have fostered a kind of sec-ond-grade literature characterized by rich hypertextual relationships (Genette). The aim of this paper is to accomplish an accurate overview of the textual and paratextual elements implied in a representative selection of adaptations of the matter and topic of the Cid. This has been preferably done with a didactic purpose and, properly contextualized in the tradition of adaptations of the Cantar de Mio Cid.This analysis allows us to check the special features that characterize this process, substantially different from the one observed in the rewriting of other works of the Spanish canon, due to factors such as the historical-legendary and literary sources of the plot, the manner and mood of the story and its performance.

Keywords: Reading promotion; reading programmes; epic poetry; Cantar de Mio Cid; literary analysis.

\footnotetext{
${ }^{\text {I }}$ Para citar este artículo: Daparte Jorge, Aldo (20I4). Reescrituras divulgativas del mito cidiano. Descripción y análisis de adaptaciones y versiones contemporáneas representativas del Cantar de Mio Cid. Alabe 10. [www.revistaalabe.com]

DOI IO.I5645/Alabe.2OI4.IO.4
} 


\section{I - La literatura en segundo grado al servicio de la mediación lectora}

Desde que las teorías sistémicas aportaron una perspectiva dinámica comunicativa y sociocultural (interferencias) al objeto de estudio de la literatura, el producto o texto ha debido compartir la atención de los estudios literarios con otros factores que conforman el sistema, como el mercado y la institución ${ }^{2}$, por su influencia determinante sobre el consumo de esta creación cultural (Iglesias Santos, I994). Los dos grandes sujetos de la mediación entre el repertorio y el lector, el editor y el profesor, a los que se han sumado diversos agentes de la revitalización del canon literario por medio de una fructífera labor de reescrituras y versiones a diferentes códigos, lenguajes y géneros de las obras más representativas que lo conforman (una literatura en segundo grado, siguiendo la expresión de Genette), han emprendido una prolífica labor de divulgación de los clásicos.

El panorama contemporáneo de esta tradición de adaptaciones presentado por García Padrino (2000: 5-6), se amplía, ya centrado en el primero de nuestros mitos literarios, en un estudio posterior (Daparte Jorge, 20I2), del que el presente ensayo pretende ser ampliación. El objetivo del primero de los trabajos dedicados a la materia cidiana es aplicar algunos instrumentos de análisis sobre la intertextualidad y la paratextualidad al estudio de las mutaciones experimentadas por aquella y, en particular, por el Cantar de Mio Cid al adecuarse a otros géneros literarios (la lírica o el teatro) y lenguajes artísticos (el cine o el álbum ilustrado) por los que ha transitado. Ahora, se pretende completar el panorama de reescrituras cidianas describiendo y enjuiciando el proceso de mayor dimensión y frecuencia: el que tiene como objetivo predominante la divulgación social y escolar del mito y del principal cantar por medio de la publicación de versiones del hipotexto básico simplemente modernizado o sustancialmente transformado en una narración actualizada.

Las razones que justifican la tarea de selección y recomposición de los textos clásicos son variadas: las obras principales del canon, sobre todo si son completas, resultan inabarcables; el objetivo básico es presentar una literatura concreta que suscite ulteriores relecturas personales del lector no iniciado; las antologías al uso, muy especialmente las que ofrecen los libros de texto de las editoriales escolares, recurso generalizado en la enseñanza media, tienen deficiencias, a veces fundamentales, sobre todo la acumulación incoherente de fragmentos de obras sin un principio organizador claro; por último, especialmente en el caso de las obras que poseen un mayor grado de estabilidad canónica, se siente la necesidad de desacralizar el concepto de formación del canon para primar el de formación del lector (Ruiz Casanova, 2007: I57).

Las adaptaciones de obras literarias con finalidad divulgativa, en este caso del Cantar de Mio Cid, objeto de descripción y valoración en este trabajo, dentro y fuera del ámbito escolar, se justifican porque hay dos niveles de lectura, uno especializado y otro general, particularmente arraigados en un contexto como el actual donde la literatura cir-

\footnotetext{
${ }^{2}$ A ambos elementos se les atribuye, en la Teoría Empírica de la Literatura, la función de actividades de mediación.
} 
cula trazando múltiples interrelaciones y formas de intertextualidad, desde la perspectiva de las teorías sistémicas a las que se aludía al principio.

El desarrollo de este proceso recreativo tiene, para Rosa Navarro Durán (2006), dos fundamentos, si no profundamente científicos, suficientemente persuasivos. Por una parte, se vale del argumento de autoridad que, en esta materia, suponen los principios a los que se atuvo la brillante adaptación del Cantar de Mio Cid emprendida por Pedro Salinas (el propósito divulgativo de hacer accesible una obra clásica, la fidelidad al original y la claridad antirretórica). Por otra, a raíz de su gratificante experiencia personal de adaptadora que ha seguido fielmente los criterios de "tan altísimo modelo" (Navarro Durán, 2006: 2), repasa tres de los trabajos de reescritura propios con el fin de realizar una apasionada justificación de tales versiones, que remacha, en las conclusiones del artículo, con el argumento básico de la necesaria reactivación de la relación dialógica entre el objeto y el receptor: se trata de la única fórmula viable para lograr resucitar del panteón de las viejas glorias a los clásicos de la literatura e impulsarlos a integrarse en el mundo de referencias culturales de los lectores actuales ${ }^{3}$.

No obstante, aun sometiéndose a los principios deontológicos básicos de respeto a la obra que Rosa Navarro reconoce en la versión de Pedro Salinas y aplica en sus propias adaptaciones y que otros autores emulan en las posteriores, como se demuestra en las páginas que siguen ${ }^{4}$, muchas de las versiones que reescriben el Cantar de Mio Cid dan prioridad al contenido básico de naturaleza argumental en lugar de construir un texto equilibrado donde la "síntesis de trama, forma y performance" (Daparte Jorge, 2OI2: 46) proporcionen plenitud de sentido a la obra recreada.

\section{2- Las trasposiciones divulgativas de la materia cidiana}

\section{I.- Las relaciones de hipertextualidad}

El texto es el único componente de la obra literaria susceptible de ser considerado literatura en el auténtico y pleno sentido del término, según las corrientes críticas que defienden un paradigma esencialista. En cambio, los elementos externos al propio texto adquieren gran relieve en las teorías sistémicas porque permiten estudiar este tipo de productos como uno de los subsistemas culturales con una dimensión pragmática o comunicativa que justifica las relaciones textuales, según los estudios de Genette (I989). El estructuralista francés ha establecido cinco grandes tipos de relaciones transtextuales: el modo intertextual, el paratextual, el metatextual, el architextual y el hipertextual. Este último tipo de relación es el que se da en varias adaptaciones del Cantar de Mio Cida las que se va a dedicar atención en este estudio.

\footnotetext{
${ }^{3}$ Es la tesis defendida con solvencia en un reciente artículo de Amando López Valero, Andrés Montaner Bueno e Isabel Jerez Martínez (2OI3): las adaptaciones de obras medievales, a veces marginadas del canon, son un trabajo que deben desarrollar investigadores y docentes con el fin de hacer asequibles a los escolares actuales textos valiosos para su educación literaria y su formación en valores.

${ }^{4}$ Marc Soriano (i995: 45) enuncia los principios por los que deben regirse las adaptaciones.
} 
Muchas creaciones literarias nuevas surgen por la mutación que experimentan unos textos con respecto a otros de los cuales derivan mediante transformación directa o imitación realizada con intenciones varias, sean estas la versión seria, la burlesca o la paródica. El primer tipo, denominado trasposición, el más frecuente, se vale de recursos que pueden suponer cambios meramente formales del texto base o transformaciones sustanciales del sentido. Las obras del canon que han experimentado largos procesos de reescritura, tanto del texto, por medio de las manipulaciones efectuadas en el mismo, como de su interpretación, a través de prólogos, reseñas, críticas o valoraciones, han acumulado una tradición de lecturas que condicionan la decodificación que haga el lector actual, de modo que estas ya han pasado a formar parte de la obra literaria.

Las referencias al hipotexto clásico, en las versiones adaptadas contemporáneas, suelen reforzarse con el componente paratextual, ya estudiado en otras reescrituras de la materia cidiana (Daparte Jorge, 2OI2), idóneo e imprescindible para un lector nuevo o escolar al que el mundo caballeresco medieval puede resultarle exótico y atractivo, especialmente las viñetas que ilustran amores, aventuras, lucha y fantasía. Únicamente en la modalidad del travestimiento burlesco destinado a adultos ${ }^{5}$ tiene lógica que el elemento paratextual exija un complejo ejercicio de interrelaciones donde las connotaciones adquieren plenitud de sentido por medio de una lectura intertextual entre el hipotexto, el hipertexto y el contexto cultural actual.

La justificación para el desarrollo de este proceso de transformación de tipo hipertextual estriba en la necesidad de compensar los perniciosos efectos que ha tenido, en el diálogo de los lectores con los clásicos, una formación literaria escolar que siempre ha concebido la obra como una "textualidad tradicional, cerrada y autoritaria por la lógica gramatical del sentido del enunciado que dicta el sujeto sobre el predicado" (Caro Valverde, 2006: 3). Investigadores y mediadores han visto, con demasiada frecuencia, el repertorio literario bajo un prisma de la literalidad coincidente total o parcialmente con el actual, al que solo era lícito el acceso por medio de la lectura de los textos originales. Además, se percibe la exigüidad de los esfuerzos dedicados a una aproximación del objeto de estudio a los contextos de recepción de los nuevos lectores de nuestro mundo posmoderno y multicultural, a pesar de que somos conscientes de que, en esta vía limitada de acceso a la literatura clásica, dicha sociedad se juega la posibilidad de tener futuros lectores competentes, conocedores de su propia tradición literaria. No obstante, la prolongada labor de adaptación de la materia cidiana a las necesidades y preferencias de los lectores noveles por medio de algunas modalidades de versión del hipotexto básico que, a continuación, se describen y valoran, puede considerarse un meritorio trabajo de promoción lectora de intensidad y calidad crecientes.

5 Antonio Orejudo, Luisgé Martín y Rafael Reig (2007). jMio Cid!. Madrid: 45I Editores. 


\section{2.- Versiones modernizadas.}

Aunque hay ediciones modernizadas del Cantar que siguen la literalidad del texto con variable fortuna en el caso de las últimas, algunas de las clásicas son las que prepararon a lo largo del siglo pasado autores como Alfonso Reyes, José Bergua, Pedro Salinas, Luis Guarner o Francisco López Estrada. Así, ya en I934, pocos años después de que viesen la luz la prosificación de Alfonso Reyes y la memorable recreación poética de Pedro Salinas, José Bergua publicó en Ediciones Ibéricas una versión más práctica del Poema del Cid provista de un prólogo con panegírico del héroe, enfoque historicista al uso y mensaje patriótico. La edición es considerada por el autor una "adaptación arqueológica" porque mantiene la mayor fidelidad posible al original al limitarse a verter a "frase corriente e inteligible aquellos conceptos que, por su oscuridad, no son comprendidos por el vulgo". Por otra parte, el contenido de las notas se limita a "aclarar en lo posible los detalles imprecisos del Poema". La versión en página contigua tiene una finalidad meramente utilitaria por lo que no es esmerada: se caracteriza por la literalidad, la adecuación de la sintaxis a un orden más actual, que rompe el ritmo y la rima del metro original. Al fin y al cabo, es pretensión declarada que esta actualización sirva de apoyo a la lectura del auténtico protagonista, el texto original ${ }^{6}$.

La versión de Pedro Salinas, disponible en red o en libro de bolsillo editado por Bienvenido C. Morros (I997) ${ }^{7}$, acompañada, en el segundo caso, con prólogo de Francisco Rico, constituye un auténtico reclamo publicitario para el lector relativamente informado de la valía del poeta y de la competencia del filólogo. El mayor atractivo del Cantar reside en que el héroe que retrata es de carne y hueso. Tiene una fuerza narrativa motivada por "constituir la entrañable recreación de un ideal de vida y, a la vez, el testimonio veraz de una encrucijada entre civilizaciones", según se dice en la cubierta. En el comentario sobre la edición, no sólo se explican las pautas seguidas para fijar el texto, sino que se pondera la calidad "inmejorable" de la versión debida a Salinas, que "hace innecesarias las notas de tipo lingüístico que suelen acompañar otras ediciones del Cantar" (Morros, I997: 54). Solo se considera precisa la información facilitada por un índice final de lugares y personajes, habitual en las versiones divulgativas de la obra.

El texto preparado por Luis Guarner aparece en varias ediciones de bolsillo a lo largo de las últimas décadas del siglo pasado, elaboradas a partir del trabajo inicial de transcripción (I944), sucesivamente retocado por el propio autor. Así, la colección Biblioteca básica Salvat de libros RTV publica en I97O una edición popular de dicho texto. La decisión responde al propósito de una editorial que, con el patrocinio de los dos medios de comunicación públicos, Radio Nacional de España y Televisión Española, pretende difundir la cultura y el libro en nuestro país, de modo que el gran público pueda formar "una auténtica y asequible biblioteca básica de alta calidad", como reza la página promocional de la colección.

\footnotetext{
${ }^{6}$ Las citas son del prólogo de Bergua (I934: I2).

7 Salinas, P. (1926). Poema del Cid. Madrid: Selecta de la Revista de Occidente. Obtenido el i de noviembre de 2 OI3 en http://amediavoz.com/cantardemiocid.htm\#Tirada\%2OI.
} 
Nada menos que Dámaso Alonso dedicará unas ilustrativas palabras con su aquilatada maestría expresiva a la edición modernizada de la misma versión textual que publica Aguilar: "Luis Guarner sigue en metro de romance la hilaza continua de nuestra épica. Es que nuestra tradición épica vivirá mientras viva España. Y siempre vivirá España” (Guarner, I976: I7). En este sentido manifiesto, están implícitas las dos ideas que fundamentan la revitalización de los clásicos: continuidad del diálogo entre estos y los receptores e identificación cultural del pueblo con su tradición cultural. Son los objetivos que se plantea el editor en las notas preliminares, siempre fiel a la conservación del "espíritu primitivo de la gesta con su sabor arcaico, dentro de la flexibilidad de nuestro castellano actual" (p. 20). He aquí la razón por la que se conservan aspectos tan importantes del ropaje fónico del cantar, como el ritmo y la rima primitivos, a diferencia de lo que ocurría en la versión más rudimentaria y utilitarista de José Bergua. No hay que olvidar que, para este autor y muchos otros, la modernización es un recurso al servicio del fin último: inducir al lector a acercarse al texto original. Se completa, en fin, la edición con unas magníficas notas que sirven de orientación explicativa, complemento cultural y aclaración de términos o conceptos para la ilustración del lector medio.

Tras la edición en prosa literaria de Alfonso Reyes, la traducción literal verso a verso de José Bergua, la versión poética tendente al verso de dieciséis sílabas hecha por Salinas y la traslación a romance octosílabo en castellano actual realizada por Luis Guarner, aparece la "labor de artesanía poética" desplegada por Francisco López Estrada (1954: LXXVIII), que podemos hallar en la colección Odres nuevos de Castalia. El autor concibe su trabajo en los términos expresados porque adapta su criterio al espíritu de la tradición épica que tan bien conoce, no con un fin creativo, sino divulgativo. Es decir, transita por la senda que marcaron Salinas y Guarner: opta por el verso octosílabo con el propósito de "seguir tras el curso de la poesía épica en las letras de España", usando "la expresión sencilla, que todos entiendan llevados más de la sugestión del relato heroico que de la adornada gracia de las palabras" (López Estrada, I954: LXXIX-LXXX) y aligerando la retórica épica. Con el sentido de la libertad poética obtenido en la recopilación y estudio de las variantes del romancero oral, se pretende entrever o emular el supuesto quehacer del juglar que pudo haber adecuado sus propias opciones a la gama de posibilidades disponibles.

Por último, como todo editor con vocación de mediador, López Estrada se manifiesta deseoso de que su trabajo sea un paso del proceso deseable que derive hacia la lectura del texto original: "Y ojalá que mi trabajo resulte un despertador de vocaciones, y lo conduzca [al lector] hasta las mismas fuentes” (López Estrada, r954: LXXXI). Y concluye su prólogo a la sexta edición de esta versión del $P$ Poema ${ }^{8}$ con una justificación de la funcionalidad mítica de dos personajes, Rodrigo y don Quijote, que respalda la renovación perenne de dos clásicos como lectura útil para los españoles (López Estrada, 1954: LXXXII).

\footnotetext{
${ }^{8}$ La sustitución del adjetivo “mío/mio", título de honor en el siglo XII, por "nuestro" a lo largo del texto es coherente con la modernización lingüística del mismo que emprende el autor. No llega al extremo de trasladar el mismo criterio al título (aparece hábilmente Poema del Cid) por el carácter emblemático y ya asentado de este signo esencial.
} 


\section{3.- Transformaciones en la modalidad textual}

A partir de la versión pionera de Ana María Moix en los años ochenta del siglo pasado $^{9}$, surge una segunda oleada de reescrituras del cantar, a veces del mito cidiano, sobre todo en editoriales escolares como Anaya, Bruño, Castalia, Edebé, Edelvives o Vicens Vives, presentadas a modo de relato en prosa fiel al original por su estructura y contenido, o bien provistas de complementos histórico-legendarios sobre la figura del héroe. El ritmo de publicaciones arreció, por razones obvias, en torno a las fechas de conmemoración relacionadas con el personaje histórico y la obra literaria. Estas ediciones tienen en común su idoneidad para un público estudiantil de enseñanza secundaria al que ni siquiera las versiones modernizadas en verso, más literales, por tanto, resultan agradables y motivadoras. Dejando al margen adaptaciones a un público infantil como el álbum ilustrado de Nuria Ochoa (2007) o la versión para títeres de Gisela López (2OOI), merece la pena detener la atención en las reescrituras más notables del período señalado.

Vicente Muñoz Puelles publicó en 2006 (Edelvives) una austera edición del Cantar que sólo incluye algunos elementos paratextuales gráficos con el papel subsidiario de ambientación para la historia. Las características técnicas de la edición se declaran en la nota previa: fidelidad al original, cuya vinculación con él se pretende reforzar citando algunos versos modernizados, respeto a la estructura tripartita y conservación del marco de referencias culturales compartido por los receptores a los que se dirigía el juglar. Concluye el comentario enunciando la función esencial que distingue al texto literario del documento histórico, acorde con los planteamientos didácticos más actuales: la literatura ha de ser "un vehículo que busca deleitar y emocionar" (Muñoz Puelles, 20o6: 9). Son las reacciones que provoca en el lector esta versión, como podemos comprobar a poco que nos adentremos como lectores en el relato: sutiles transformaciones y adiciones en el episodio de la salida de Vivar o en el de la niña de nueve años, por ejemplo, lo demuestran con un simple cotejo de este texto y el correspondiente original (Muñoz Puelles, 2006: I5 y 20). Por último, como es habitual en las demás ediciones, se contextualiza la escena inicial presentando el supuesto contenido de la hoja perdida del códice tomado de las crónicas y se amplía el final del Cantar con elegancia escueta aludiendo al destino final del cuerpo del protagonista y a la perduración de la historia (Muñoz Puelles, 2006: I54).

Esta fidelidad al contenido del hipotexto no tiene su paralelo en los recursos formales y estilísticos: difícilmente podría conciliarse la lectura apasionada de un joven actual con la austeridad expresiva del Cantar y su universo completo de referencias, a veces demasiado sutiles, que manifestarían su plena eficacia en el específico proceso de performance oral. Un detalle significativo puede citarse como ejemplo de esta afirmación: en el episodio del conde de Barcelona, la despedida irónica del Cid con la expresión anfibológica reproducida en el verso Io68 ("Ya vos ides, conde, a guisa de muy franco!" "о) ha desaparecido. El juego de palabras a que da lugar el término "franco", en su doble

\footnotetext{
${ }^{9}$ Ver apartado 2.5 .

${ }^{\text {Io }}$ Cito por la edición de Montaner (2003).
} 
acepción de ‘hombre libre’ y ‘catalán’ (esta segunda en boca del Cid victorioso a quien se acaba de mencionar como "el castellano" está cargada de ironía) se situaba en el contexto de un episodio de enfrentamiento entre los rudos castellanos y unos enemigos cortesanos y elegantes, inadecuadamente pertrechados para el fragor de la batalla.

Otra "adaptación” (así denominada en la portada interior), llevada a cabo por Emilio Fontanilla Debesa (2007) sigue unos criterios parecidos a la anterior en lo que respecta al contenido de la historia y a los elementos paratextuales. Las ilustraciones, de trazo grueso, son figuras hieráticas y angulosas que recrean el aspecto de las imágenes reproducidas en las vidrieras góticas. Su contenido, relacionado con temas o episodios del Cantar, es, a veces, decorativo y, frecuentemente, emotivo (escenas familiares) o bélico. Otros elementos paratextuales como el prólogo y el apéndice, con un claro enfoque didáctico, proporcionan al lector información amplia y actualizada sobre el contexto histórico-cultural, el género, la obra y sus aspectos literarios más relevantes, así como la potencialidad artística de la misma para satisfacer las expectativas de un receptor de hoy. El destinatario previsto es "un lector joven actual" al que se ofrece un texto "modernizado y simplificado" lingüísticamente (Fontanilla Debesa: Io), sin perder la fidelidad temática y estilística al original. Únicamente se reconoce la expurgación de pasajes secundarios reiterativos que, podemos añadir, sólo cobran su auténtico sentido en una performance como la desarrollada en el mundo juglaresco, hoy irrecuperable. Un apresurado cotejo de algunos fragmentos con la edición comentada antes confirma una literalidad más servil con respecto al Cantar en este caso: la despedida de Vivar (p. I4), el episodio de la niña burgalesa (p. I5), el episodio del conde don Ramón (pp. 49-52), etc.

También la edición de Rosa Navarro Durán (2007) es propensa a la literalidad, como demuestra un detalle tan significativo del estilo oral formulario original como es la conservación del epíteto épico. Tomemos como ejemplo el episodio en que Martín Antolínez provee de los primeros víveres al Cid recién desterrado. El texto de Rosa Navarro lo reproduce de forma similar al de Fontanilla Debesa y al de Francisco Alejo: Martín empieza su discurso, después de abastecer de pan y vino a los desterrados, con la fórmula “¡Campeador, en buena hora naciste!” (Navarro Durán, 2007: I5), “¡Oh, Campeador, en buena hora nacido!" (Fontanilla Debesa, 2007: I6) y "Oh Campeador, en buena hora nacisteis!” (Alejo, 2OIO: I3). Responde el interpelado con otro parlamento iniciado con la expresión estereotipada “ ¡Martín Antolinez, sois una lanza atrevida!” (Navarro), “Martín Antolinez, caballero de intrépida lanza!” (Fontanilla), y “Martín Antolinez, sois un valiente guerrero!" (Alejo). Obsérvese también el uso de la fórmula arcaizante de tratamiento "vos" en un texto modernizado con el fin de mantener el sabor de época del discurso.

Tampoco se pierde de vista, en este caso, implícitamente, que el trayecto del lector iniciado debe terminar en el texto original, por lo que se seleccionan fragmentos del mismo con la correspondiente versión de Pedro Salinas y cuestionarios sobre dicha modernización y el contenido de los fragmentos. Los apéndices, en los que, además de esta antología, se reproduce un breve estudio del texto y un amplio cuestionario focalizado sobre la narración y otras cuestiones de la obra literaria, enmarcan el libro dentro de una 
orientación plenamente didáctica de uso escolar.

Por último, de las ediciones de este tipo, la más reciente es la preparada por Francisco Alejo (2OIO), similar a las anteriores, a excepción de un elemento paratextual consistente en una guía de lectura que no incita a la actividad sobre la obra, sino que aporta información acerca de aspectos contextuales y literarios relacionados con el personaje protagonista y la obra adaptada. El propósito declarado por los editores concuerda con el producto ofrecido, las cualidades del libro y los textos y paratextos que contiene: "con la adaptación de F. Alejo nos resultará fácil y atractivo conocer las hazañas del Cid en un relato fiel al original transmitido por los juglares”. El expresionismo y fuerte colorido de las imágenes pueden ayudar como reclamo para un lector adolescente cautivado por el atractivo y la facilidad de las lecturas de las que gusta como consumidor espontáneo.

\section{4.- Alteración de la extensión original}

El cambio de extensión con relación al hipotexto es otra opción de reescritura que podría ejemplificarse con la versión resumida del Cantar realizada por Domingo de Isabel (2007) el año de la última conmemoración del aniversario del códice, editada por la Junta de Castilla y León. Mediante el manido recurso de la analepsis, se presenta a un héroe ya retirado, en una jornada de caza, anacrónicamente escéptico ante el valor y los fines de sus hazañas pretéritas. El episodio, fruto de la invención del autor, aunque esté salteado de alusiones a hechos históricos relacionados con el protagonista y aparezcan en él personajes del cantar de gesta, sirve de marco narrativo que justifica la recuperación del relato del códice por medio de las artes que ejercita el amigo alquimista de Rodrigo, de nombre Shamir. Este permite al héroe, mediante un encantamiento, ver reflejadas en las aguas del río a un juglar dispuesto a recitar "la gesta de mío Cid el de Vivar" (Domingo de Isabel: I5) en el escenario más típico, la plaza de un pueblo. Antes de proceder a relatar el contenido de cada uno de los cantares, se dispone un paratexto expositivo ("Tras la leyenda") dedicado a presentar al personaje protagonista, a describir la labor de los juglares y a dar noticia del manuscrito del Cantar, acompañado de ilustraciones de Irene Fra Gálvez que imitan las figuras de miniaturas y códices medievales. De estilo muy diferente son las viñetas que adornan el relato (Felipe López Salán): diseñadas con trazo limpio, parecen querer poner ante los ojos del lector momentos que el juglar pretende hacer imaginar a la audiencia. No hay otros elementos paratextuales que induzcan a pensar que la adaptación se destina al trabajo escolar posterior a la lectura del texto, sino que parece planificada para el disfrute por parte de un lector joven.

El narrador del relato primero tiene el gran acierto de incluir en él, de manera esporádica, notas descriptivas del ambiente que hay en la plaza donde actúa el juglar, con el que interactúan los espectadores, de modo que se consigue una aproximación bastante fiel a la representación pública de los cantares de gesta. La grafía y el lenguaje utilizados contribuyen a facilitar la discriminación automática entre ambos niveles de la narración: el relato externo se reproduce con letra redonda convencional y está redactado en una variedad lingüística actual, con vivos rasgos coloquiales en los discursos de los personajes, 
mientras que el texto que adapta el cantar de gesta, en letra cursiva, se caracteriza por su hieratismo y una moderada modernización de la lengua. Se consigue, pues, una aceptable fusión de ambos tipos de texto, en los que se ensamblan fragmentos de una tercera modalidad (informativa, como se ha visto) con el objeto de lograr un producto idóneo para una lectura estimulante desde la perspectiva de un joven actual, habituado a recursos narrativos similares a los aquí usados (flash-back, elementos maravillosos, lenguaje coloquial, discontinuidad en el relato...) en la literatura y el cine de consumo habitual.

\section{5.- Ampliación del argumento básico del Cantar}

Las versiones de la tradición cidiana como complemento del argumento básico del Cantar de Mio Cid son otra modalidad de reescritura adoptada en algunas de las ediciones más destacadas de la materia, fruto de la inventiva de creadores o editores consagrados, como Ana María Moix, McCaughrean y Montaner, Sánchez Aguilar o Monserrat del Amo. El tema cidiano, en su desarrollo histórico, ha generado materiales literarios y legendarios que han servido para completar la imagen ficticia que del héroe da el Cantar a la hora de crear nuevas adaptaciones divulgativas del mito. De las cuatro aludidas, tres suelen ser las más utilizadas por los mediadores en el ámbito escolar para acercar el venerable poema a los adolescentes actuales.

La versión de Ana María Moix (i984) tiene el mérito de suponer una avanzadilla en la avalancha de reescrituras del Cantar o la leyenda del Cid de las últimas décadas. En el prólogo, se sintetizan los frutos artísticos que produjo la recreación del tema hasta la actualidad, algunos de ellos tomados como complemento del cantar de gesta para la confección de la versión de la autora (Las mocedades de Rodrigo y el Romancero). En una primera parte, se recrea la juventud del personaje a partir de la obra de Guillén de

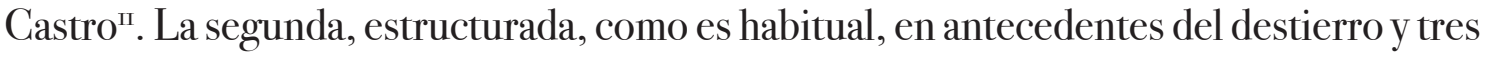
cantares, se completa con los hechos históricos y legendarios conocidos de la muerte del héroe en Valencia y su victoria sobre los moros siendo ya cadáver, episodio debidamente arreglado por la creatividad de la escritora.

Los principales efectos de la reescritura realizada a partir del original se perciben tanto en el texto como en el tono del relato. El protagonista sigue siendo un personaje idealizado - "Pero ni el oro ni las joyas ni los brocados de seda hacen olvidar a Rodrigo lo que más desea: congraciarse con su rey" (p. 57)-, pero se ha perdido un rasgo característico de su talante, el humor irónico, debido a decisiones técnicas que afectan al contenido del relato; en este caso, el resumen que se hace de episodios que remarcaban esta faceta de la personalidad del héroe (el episodio de las arcas de arena o el encuentro con el conde de Barcelona), a cuyo contenido se aludió en apartados anteriores. En el primero de ellos, se actualiza el recurso humorístico porque los judíos mencionan los bienes que van a custodiar con su peculiar codicia ("arquitas", p. 54); pero, en el segundo, simplemente desaparece porque sintetiza escuetamente el episodio la voz del narrador: "El Cid ha vencido al conde Ramón Berenguer, a quien ha ganado la espada Colada”, p. 59).

\footnotetext{
${ }^{\mathrm{II}}$ Las mocedades del Cid (1618).
} 
Por otra parte, la caracterización de los personajes se hace sin los matices y la contención narrativa propios del Cantar, de manera descarnada y despectiva, en el caso de los antagonistas, por medio de agrias expresiones: "te has convertido en el terror de la morisca", dice Martín Antolínez al héroe tras la retahíla de victorias; "los terribles Fáriz y Galve", p. 57; "Y la visión descompone sus cerebros supersticiosos", que describe la reacción de los moros ante la imagen del Cid muerto cabalgando (p. 57). En el caso de los judíos, se cargan las tintas en una tópica codicia no disimulada que provoca la pérdida de toda la sutil maestría demostrada por el autor juglaresco en el original (p. 54). El maniqueísmo expresivamente desplegado en la versión modernizada se percibe también en el caso de la caracterización de los antagonistas cristianos: no se ahorra adjetivación que ponga de relieve la baja catadura moral de los infantes (pp. 73-75).

Obviamente, no queda rastro del lenguaje característico del relato heroico, con su austeridad y estilo formulario, que han sido sustituidos por la vulgar expresión del registro coloquial contemporáneo, mediatizado incluso por rasgos del lenguaje cinematográfico y televisivo: “'Rata cobarde!” exclama Pero Bermudo dirigiéndose al infante don Fernando (p. 84); “¿Dónde están esas arquitas?”, inquieren Raquel y Vidas (p. 54).

Las reescrituras publicadas en Bruño y Vicens Vives logran una presentación atractiva para lectores adolescentes, con despliegue de paratextos, materiales y diseño general acordes con las expectativas de un receptor habituado a consumir productos culturales que siguen esta estética cuidada y llamativa. Las ilustraciones a todo color, con imágenes de gran expresividad y reproducción de pasiones y sentimientos, desde las cubiertas hasta las páginas del libro, son una marca distintiva de la segunda editorial citada. El ilustrador de la versión preparada por Mc Caughrean y Montaner (2000) es Víctor G. Ambrus; en la de Sánchez Aguilar (2007), se hace cargo de las imágenes Jesús Gabán. Del relieve que adquiere el elemento visual, da testimonio no sólo la cubierta que representa a un Cid cabalgando triunfante, con Jimena a su lado, por las afueras de una Valencia de exótico aire oriental, en un caso, y al héroe con sus tropas en plena carga, lanzas en ristre, en el segundo, sino también que se traigan a esta posición destacada del libro los nombres de los ilustradores citados.

No ocurre esto en la edición de Bruño, donde el despliegue de colores vivos ha desaparecido de unas ilustraciones diseñadas por Fuencisla del Amo que recrean un ambiente medieval tópico e idealizado. Se repite en todos los márgenes de las páginas, excepto en las reservadas al taller literario, una pequeña silueta de un Cid estático, a caballo, blandiendo su espada. Es la misma figura de la portada, que, en cambio, presenta al héroe de frente, en primer plano sobre un fondo de paisaje gris con castillo, retratada su figura en cálidos tonos dorados, desprovista de casco, lo que permite resaltar su humanidad reforzada por una expresión meditabunda y la mirada perdida en pos de algún ideal firme. El cabello al viento y ligeramente despeinado sugieren un dinamismo contenido y, a la vez, la consiguiente fatiga que se deriva de la lucha continua. La expresión de serenidad refleja la sapientia del personaje. La vista perdida en el horizonte permite vislumbrar que lo animan grandes ideales. Por último, la espada empuñada con aire seguro confirma la característica fortitudo del héroe. 
Mc Caughrean y Montaner (2000: 33) tienen el propósito expreso de realizar una adaptación "en toda regla". Para acercar el contenido de la narración a quienes se están iniciando en la lectura de los clásicos, no basta una actualización lingüística como las emprendidas por Salinas o Cela ${ }^{12}$, sino que hay que reescribir "un texto más acorde con los modos de narrar de hoy en día" (p. 32), lo que implica eliminar aspectos tan específicos del relato épico como las fórmulas, las series gemelas o la narración doble. Sobre la base del hilo argumental del poema, se procede a "cierta novelización" (p. 33) que imprime más ritmo al relato y ayuda a recrear el ambiente, pero que se evita en momentos culminantes del desarrollo de la trama. Mayor creatividad se permiten, en cambio, al principio, donde recrean el enfrentamiento entre García Ordóñez y Rodrigo Díaz y la leyenda de la bastardía que afecta al héroe. También optan por remediar el final abrupto del Cantar trasladando a ese punto al mencionado conde enemigo del Cid para convertirlo en causante indirecto de la muerte de este. Añaden, por último, el episodio de más arraigo popular por su gran efectividad narrativa en una versión con orientación novelesca: la victoria del Cid después de muerto sobre los moros que asedian Valencia.

Los criterios seguidos para la adaptación, siempre que se acepte este ejercicio aplicado a los clásicos, parecen aceptables por su equilibrio, siempre que la calidad literaria del texto se atenga a los criterios más exigentes. Algunas calas en la obra que se está comentando demuestran un trabajo concienzudo de recreación textual: creatividad por medio de la utilización de figuras retóricas como el símil en la primera escena del Cantar, fragmento fundamental de la obra, que transmite gráficamente al receptor la sensación de vacío y abandono apresurado ("En las casas de Vivar las perchas quedaron vacías como cuernos de toro", p. 45); otro ejemplo logrado del mismo recurso lo encontramos más adelante: "Como las campánulas rojas que de pronto yerguen sus cabezas para permitir a los cálidos vientos que se lleven su semilla, el Cid pareció crecer en estatura” durante las cortes (p. I6I); reconversión de algunas fórmulas en expresiones actualizadas, en lugar de optar por su eliminación (“Dios te salve, don Rodrigo Díaz de Vivar. El día en que tú naciste el mundo entero resplandeció y los planetas bailaron en el cielo de puro gozo", p. 54); el episodio del conde de Barcelona se expande, sin perder la tensión burlona del diálogo entre los dos cabecillas (pp. 90-95); no se cae en el anacronismo fácil, sino que se respeta el espíritu de la época y la obra, como reflejan fragmentos donde se dan enfoques contrastantes acerca del enemigo musulmán: “Desde allí se extendía Alandalús, el territorio poblado por los musulmanes que todo cristiano se consideraba con derecho a recuperar para su rey y su fe" (p. 6r), entre los que, por supuesto, se encuentra el Cid (“¡Tomo posesión de Alcocer en nombre de Dios y del rey Alfonso! Quiera el Señor rendir a sus pies cada una de las ciudades tomadas a los paganos por este humilde servidor", p. 68), quien, sin embargo, no duda en ser generoso y tolerante cuando conviene ("Los moros de Castejón aclamaron a don Rodrigo y, desde aquel día, en el ejército del caballero de Vivar hubo también guerreros musulmanes", p. 66).

${ }^{12}$ Poema del Cid, Cantar I(1957-1959). 
Otra edición adaptada de la obra con formato y pretensiones similares a las manifestadas en la anterior es la preparada por Agustín Sánchez Aguilar (2007) bajo el título La leyenda del Cid. Ahora bien, tanto este como los textos de la contraportada dejan entrever intenciones parcialmente diferentes a las expresadas por Mc Caughrean y Montaner. En este caso, se trata de ofrecer al lector "un absorbente libro de aventuras", donde abunden la acción, la descripción lírica de los sentimientos y un estilo literario "cautivador". La primera recreación origina episodios introductorios y de colofón para enmarcar el texto base del Cantar; en cambio, esta amplía la limitada información del poema épico con la que han legado otras fuentes medievales y áureas de naturaleza literaria y legendaria para conformar una imagen más completa del personaje, concebido como mito.

Ambas versiones comparten, en lo que se refiere al desarrollo de la trama, la necesidad de novelar para dar profundidad a la historia y provocar el adecuado impacto emocional en un receptor actual, si bien se mantiene "el tono solemne de la épica" en el texto de Sánchez Aguilar (2007: 8), pues conviene a los relatos de héroes y "genera una cierta distancia entre el autor y el lector que favorece la idealización del protagonista, objetivo casi irrenunciable entre quienes cultivan la épica, y que se manifiesta por igual en los viejos cantares medievales sobre la corte del rey Arturo que en las modernas novelas del oeste". El marchamo y dignidad heroicos del discurso se percibe, por ejemplo, en las intervenciones del Cid durante el juicio celebrado contra los infantes, la descripción lírica de los sentimientos en las relaciones de afecto del protagonista con los humildes, las mesnadas, o la familia y la calidad literaria de la prosa en el uso figurado de la lengua que señalábamos también en el texto de Mc Caughrean y Montaner.

El último de los rasgos merece una ejemplificación que atestigüe la calidad literaria del texto resultante de la recreación. Comienza la despedida de Vivar con un símil que, por tópico, no deja de cumplir la función de humanizar al protagonista: "Llorando sin consuelo como un niño, así partió Rodrigo hacia el destierro" (p. III). ¿Un héroe invadido por un llanto indigno de su personalidad? No, como justifican las razones posteriores. Tras las palabras de la niña burgalesa, "roto de dolor, el Cid agachó la cabeza" (p. II4) vencido, como el rudo héroe de la versión lírica del episodio escrita por Manuel Machado, por la demoledora ternura de una insignificante y anónima criatura, aquel que no se hubiera inmutado ante los temibles ejércitos almorávides. A veces, las imágenes del texto original son insuperables; sólo se trata de darles una expresión actualizada. La amarga despedida de Cardeña merece el siguiente comentario al juglar, retomado por el novelista moderno: "Si le hubieran arrancado las uñas de cuajo, no habría sentido un dolor tan grande” (p. 128). De todas ellas, quizá la que mayor tono heroico aporta es la que pondera la barba del Cid, a la que se mantienen las alusiones en estos ejemplos de reescritura del clásico por lo que conserva de símbolo indeleble: durante las cortes, "mientras las barbas de todos los demás lucían sueltas, la del Cid aparecía maciza y desafiante como un asta de lanza" (p. 202).

Finalmente, como corresponde a un relato que ha adoptado la apariencia novelesca, se desecha la estructura tripartita establecida por Menéndez Pidal para seguir la línea 
de las dos adaptaciones comentadas antes: la división en capítulos más breves con título particular alusivo al contenido en cada uno de ellos. Monserrat del Amo (2006) los complementa, en la parte previa a la que sigue el texto del Cantar, con unos versos introductorios modernizados que ha tomado del Romancero y, a partir de la escena del destierro, con citas del propio poema épico. Tras esta "puesta en escena", la autora se aplica a "traducir poéticamente" los episodios más importantes del cantar de gesta con la amenidad, sencillez y vitalidad que caracterizan su prosa con la voluntad de divulgar el clásico entre los jóvenes.

A ese tipo de lector orienta expresamente Monserrat del Amo el prólogo de la edición, en el que repasa la tradición del tema cidiano y explicita los criterios que han guiado su labor de adaptadora: selección de pasajes del original, respeto al fondo de la historia y complemento de la trama del Cantar con documentación sobre los años de vida del personaje previos al trecho existencial en el que se centra la gesta, con la excepción de la infancia de Rodrigo, fruto de la invención de la escritora. Y termina este paratexto con dos ideas muy apropiadas para las ediciones didácticas, en las que no debe haber una renuncia a los valores imperecederos ocultos que atesoran los clásicos: por una parte, la historia narrada no se fundamenta en un maniqueísmo simplificador, sino que transmite "un mensaje de fe, de amor, de honradez, de paz, de lealtad y de justicia" (p. I2); por otra, nos proporciona una lección que previene al lector contra el desánimo: “el fracaso, si se acepta con realismo y se supera con valor, puede convertirse en el primer paso del camino que conduce al verdadero éxito, como le ocurrió al Cid Campeador” (pp. I2-I3).

La alteración del argumento básico del Cantar por medio de la selección, las licencias que se permite la autora de la adaptación, la mezcla de ciertas expresiones literales de la gesta con un lenguaje coloquial moderno y el predominio absoluto de un diálogo constituido por parlamentos breves y ágiles convierten el texto resultante en un recurso idóneo y necesario para un acercamiento del receptor inexperto al clásico, del que hay múltiples versiones adecuadas para niveles de lectura más avanzada, como se ha visto en casos anteriores.

\section{3-Conclusión}

La lectura no puede limitarse al proceso cognitivo de la comprensión, sino que deben producirse el reconocimiento estético y la actitud lúdica que conforman la auténtica competencia literaria, concepto paralelo al de competencia lingüística ${ }^{13}$. La práctica de la formación literaria daba prioridad al análisis de la "organización microestructural donde se manifiestan los efectos estilísticos", porque la "macroestructura que permite una visión global” (López Valero, I998: 226) requeriría la lectura comprensiva de las obras

I3 Mendoza Fillola desarrolla el concepto en "La competencia literaria: una observación en el ámbito escolar", Tarifa, 5 , Universidad de Cádiz, 1988. 
completas, inaccesible para los lectores noveles. La creación de una relación intersubjetiva entre el objeto y el receptor aplicando los recursos técnicometodológicos que la faciliten es la condición previa para que se dé una adecuada recepción de las formas y los temas literarios. Además, es preciso determinar las condiciones de representación y recepción de los textos, cuya lectura no se produce en el vacío, sino en interacción con factores de orden individual y colectivo. Las reescrituras de obras clásicas se plantean, a este respecto, como un recurso metodológico que pretende franquear el acceso del receptor principiante al objeto artístico, aun a costa de desvirtuar su textualidad, por medio de una estrategia de aproximación a las expectativas del joven actual consistente en desplegar recursos textuales y paratextuales que no sean extraños en su curriculum oculto ${ }^{\mathrm{I}}$.

En plena crisis de la Humanidades, el punto de llegada más aceptado y asentado, tras prolongada tradición de renovación didáctica, es la práctica de la interdisciplinariedad, con dosis de interculturalidad e, incluso, como defiende Caro Valverde (2006), la interactividad entre diferentes niveles. Se deben proponer métodos universalmente válidos, creativos, motivadores que, en el caso del trabajo con los clásicos, se alejen de la textualidad cerrada tradicional. Se propugna, pues, una ineludible aproximación dialógica a los textos canónicos, alejada tanto de la lectura consumista como de la analítica, que se adecue al perfil específico del receptor principiante y sus circunstancias.

Las adaptaciones de obras canónicas pueden contribuir, con el apoyo de recursos técnicometodológicos interdisciplinares a disposición de los mediadores, a un acercamiento inicial e ilustrativo a los elementos contextuales y argumentales básicos, válido en las primeras fases del proceso lector e, incluso, a reconstruir ciertos componentes del horizonte de expectativas original de las obras literarias creadas en un ámbito de oralidad dominante. Ahora bien, su uso no debe suplir la utilización preferente de antologías de textos modernizados y organizados coherentemente en torno a motivos o ejes temáticos, tesis defendida por Daparte Jorge (2012: 45) ז5 $^{5}$ al menos en los niveles intermedios de competencia lectora, método que permite paliar las carencias y deficiencias vistas en las adaptaciones, profundizar en el conocimiento de la construcción formal de las obras para desentrañar satisfactoriamente su contenido e, incluso, para poder reutilizar esos recursos formales en la exposición de las propias vivencias, operaciones específicas de una auténtica formación literaria. La obra adaptada tampoco puede ser considerada un recurso terminal, sino propedéutico, un incentivo para el encuentro pleno del futuro lector competente con la obra original.

\footnotetext{
${ }^{\text {I4 }}$ Expresión utilizada por Gloria García Rivera (2004: I5) para referirse a las experiencias literarias y culturales previas que deben ser tenidas en cuenta en el desarrollo del proceso psicológico del aprendizaje lingüístico-literarı.

I5 Sobre los distintos factores implicados en la elaboración de las antologías, relacionados con los propuestos por la Teoría Empírica de la Literatura a los que se alude al principio de este artículo, puede verse el trabajo reciente publicado en esta revista: Blarzino, Andrea (2OI4). Un modelo de aproximación formal al "libro llamado antología". Alabe $g$ (www.revistaalabe.com) DOI IO.I5645/Alabe.2OI4.9.2.
} 


\section{Referencias bibliográficas}

-Alejo, F. (Ed.) (20Io). Cantar de Mío Cid. Rogelio Quintana (Ilustr.). Madrid: Castalia Fuente.

- Bergua, J. (Ed.) (1934). Poema del Cid. Madrid: Ediciones Ibéricas.

- Blarzino, Andrea (2OI4). Un modelos de aproximación formal al "libro llamado antología". Álabe g. (www.revistaalabe.com) DOI ı.I5645/Alabe.20I4.9.2.

- Caro Valverde, Ma T. (2006). Los clásicos redivivos (modelo didáctico interdisciplinar en educación literaria). Murcia: Dpto. de Didáctica de la Lengua y la Literatura, Universidad de Murcia.

- Conde, J. C. (Ed.) (r999). Cantar de Mio Cid. Ramón Menéndez Pidal (Texto med.) y Alfonso Reyes (texto mod.). Madrid: Espasa-Calpe, Col. Austral.

- Daparte Jorge, A. (2OI2). Descripción y análisis de las reescrituras y versiones de la materia cidiana al servicio de la mediación lectora. Ocnos, 8, 33-48.

-Del Amo, M. (2006). Andanzas del Cid Campeador. Hugo O’Donnell (Pról.) Fuencisla del Amo (Ilustr.). Madrid: Bruño.

- Domingo de Isabel, Á. A. (2007). Rodrigo, un caballero de leyenda. Adaptación del Cantar de Mío Cid. Felipe López Salán e Irene Fra Gálvez (Ilustr.). León: Junta de Castilla y León.

- Fontanilla Debesa, Emilio (Ed.) (2007). Cantar de Mio Cid. Anónimo. Esther Pili (Ilustr.). Madrid: Anaya.

- García Padrino, J. (2000). Los clásicos en las lecturas juveniles. Biblioteca Virtual Miguel de Cervantes. Obtenido el I de noviembre de 2013 desde http://www.cervantesvirtual.com/ images/iconos/html.png.

- García Rivera, G. (2004). Didáctica de la Literatura. Cuestiones generales. En A. López Valero y E. Encabo Fernández (Coord.). Didáctica de la Literatura. El cuento, La dramatización y la animación a la lectura (pp. I5-34). Barcelona: Octaedro-EUB.

- Genette, G. (I989). Palimpsestos. La literatura en segundo grado. Madrid: Taurus.

- Guarner, L. (Ed.) (г970). Poema de Mio Cid. Estella: Salvat-Alianza.

- Guarner, L. (Ed.) (1976). Poema de Mio Cid. Ramón Menéndez Pidal (Texto med.) y Luis Guarner (texto mod.). Madrid: Aguilar.

- Guarner, L. (Ed.). Cantar de Mio Cid. Texto med. y mod. Madrid: Edaf, I980. 
- Iglesias Santos, M. (i994). El sistema literario: Teoría Empírica y Teoría de los Polisistemas. En D. Villanueva (Comp.). Avances en...Teoría de la Literatura (pp. 3o9-356). Santiago de Compostela: Universidad.

- López, G. (200I). El Cid. Adaptación para teatro de títeres (Compañía “El Retal”). Madrid: Asociación Española de Teatro para la Infancia y la Juventud (AETIJ).

- López Estrada, F. (Ed.) (I954). Poema del Cid. Versión métrica modernizada. Madrid: Castalia, Col. "Odres nuevos".

- López Estrada, F. y Roselló Verdeguer, J. (Eds.) (2002). ElCidCampeador. Madrid: Castalia Prima.

- López Valero, A.; Montaner Bueno, A. y Jerez Martínez, I. (2OI3). Reinventando la didáctica de los textos medievales en Educación Secundaria. Aproximación al Libro del caballero Zifary al Libro del conde Lucanor. Dialogía, 7, 268-29I.

- Martín Rogero, N. y Muñoz Álvarez, A. (2009). Adaptaciones, selecciones y antologías. En Ma V. Sotomayor Sáez (Coord.). El Quijote para niños y jóvenes. 1905-2008. Historia, análisis y documentación (pp. п7-225). Cuenca: Ediciones de la Universidad de Castilla-La Mancha.

- McCaughrean, G. y Montaner, A. (2000). ElCid. Víctor G. Ambrus (Ilustr.). Madrid: Vicens Vives.

- Moix, A. Ma . (I984). Cantar de Mio Cid (adaptación). José Bellalta (Ilustr.). Barcelona: Lumen.

- Montaner Frutos, A. (Ed.) (1993). Cantar de Mio Cid. Barcelona: Crítica.

- Morros, B. C. (Ed.) (1997). Cantar de Mio Cid. Francisco Rico (Pról.), Bienvenido C. Morros (Texto med.), Pedro Salinas (Texto mod.). Barcelona: Plaza \& Janés.

- Muñoz Puelles, V. (Ed.) (20o6). El Cantar de Mío Cid. Pablo Auladell (Ilustr.). Zarago-za: Edelvives.

- Navarro Durán, R. (2006). ¿Por qué adaptar a los clásicos? TK, I8, I7-26. Obtenido el de noviembre de 20I3 desde www.asnabi.com/revista-tk/revista-tk-I8/o3navarroduran.pdf.

- Navarro Durán, R. (Ed.) (2007). Cantar de Mio Cid. Carles Arbat (Ilustr.). Barcelona: Edebé.

- Ochoa, N. (2007). El Cid. Texto basado en la Historia Roderici y en el Cantar de Mio Cid. Anónimos. Cristina Picazo (Ilustr.). Madrid: Santillana.

- Reyes, A. (Ed) (r9i9). Poema del Cid. Madrid: Espasa-Calpe. 
- Rodiek, Ch. (1995). La recepción internacional del Cid. Madrid: Gredos.

- Ruiz Casanova, J. F. (2007). Anthologos: Poética de la antología poética. Madrid: Cátedra.

- Sánchez Aguilar, A. (2007). La leyenda del Cid. Madrid: Vicens Vives.

- Soriano, M. (1995). La literatura para niños y jóvenes. Guía de exploración de sus grandes temas. Buenos Aires: Colihue.

- Sotomayor Sáez, Ma V. (2005). Literatura, sociedad, educación: las adaptaciones literarias. Revista de Educación, No Extra I, 2I7-238.

- Sotomayor Sáez, Ma V. (Coord.) (2009). ElQuïote para niños yjóvenes. 1905-20o8. Historia, análisis y documentación. Cuenca: Ediciones de la Universidad de Castilla-La Mancha. 